\title{
Epidemiology of hidradenitis suppurativa in Poland in relation to international data
}

\author{
Epidemiologia hidradenitis suppurativa w Polsce na tle danych światowych
}

\author{
Łukasz Matusiak', Andrzej Kaszuba², Dorota Krasowska³, Waldemar Placek', Jacek Szepietowski' \\ 'Department of Dermatology, Venereology and Allergology, Wroclaw Medical University, Poland \\ 2Department of Dermatology, Paediatric Dermatology and Dermatological Oncology, Medical University of Lodz, Poland \\ ${ }^{3}$ Department of Dermatology, Venereology and Paediatric Dermatology, Medical University of Lublin, Poland \\ ${ }^{4}$ Department of Dermatology, Sexually Transmitted Diseases and Clinical Immunology, University of Warmia and Mazury in Olsztyn, Poland \\ 'Katedra i Klinika Dermatologii, Wenerologii i Alergologii Uniwersytetu Medycznego we Wrocławiu, Polska \\ ${ }^{2}$ Katedra i Klinika Dermatologii i Dermatologii Dziecięcej i Onkologicznej Uniwersytetu Medycznego w Łodzi, Polska \\ ${ }^{3}$ Katedra i Klinika Dermatologii, Wenerologii i Dermatologii Dziecięcej Uniwersytetu Medycznego w Lublinie, Polska \\ ${ }^{4}$ Katedra i Klinika Dermatologii, Chorób Przenoszonych Drogą Płciową i Immunologii Klinicznej Uniwersytetu Warmińsko-Mazurskiego \\ w Olsztynie, Polska
}

\section{CORRESPONDING AUTHOR/ ADRES DO KORESPONDENCJI:} dr hab. n. med. Łukasz Matusiak Katedra i Klinika Dermatologii, Wenerologii i Alergologii Uniwersytet Medyczny we Wrocławiu ul. Chałubinskiego 1 50-368 Wrocław, Polska tel.: +48717842333 e-mail: luke71@interia.pl

\begin{abstract}
Hidradenitis suppurativa (acne inversa) is a chronic, inflammatory, recurrent, debilitating disease of hair follicles manifested by painful, deepseated, inflamed lesions localized in intertriginous areas. Establishing a correct diagnosis seems straightforward enough, as it is based on clinical criteria, but a comparative analysis of published papers on hidradenitis suppurativa epidemiology easily reveals substantial discrepancies in the estimation of the obtained results for the general population. Data on the prevalence of hidradenitis suppurativa in European countries and in the United States of America differ by up to four orders of magnitude, ranging from $0.00033 \%$ to $4.1 \%$. Based on data obtained from the Polish National Health Fund and HS reference centres, the prevalence of hidradenitis suppurativa in Poland was estimated at $0.001 \%$, which classifies hidradenitis suppurativa as a rare disease.
\end{abstract}

\section{STRESZCZENIE}

Hidradenitis suppurativa (trądzik odwrócony) jest przewlekłą, zapalną, nawrotową, wyniszczającą dermatozą mieszków włosowych, która objawia się występowaniem bolesnych, głęboko umiejscowionych zmian zapalnych zlokalizowanych $\mathrm{w}$ okolicach wyprzeniowych. Chociaż postawienie prawidłowej diagnozy wydaje się proste, bo opiera się na kryteriach klinicznych, to przyglądając się pracom epidemiologicznym dotyczącym hidradenitis suppurativa, łatwo dostrzec znaczne rozbieżności w estymacji uzyskiwanych wyników na populację ogólną. Szacunkowe dane dotyczące częstości występowania hidradenitis suppurativa $\mathrm{w}$ krajach europejskich i USA różnią się od siebie nawet o 4 rzędy wielkości i mieszczą się w przedziale od $0,00033 \%$ do $4,1 \%$. Na podstawie danych z Narodowego Funduszu Zdrowia oraz z ośrodków referencyjnych dla hidradenitis suppurativa oszacowano częstość występowania hidradenitis suppurativa w Polsce na 0,001\%, co kwalifikuje hidradenitis suppurativa jako chorobę rzadką. 
Key words: hidradenitis suppurativa, acne inversa, epidemiology, Poland. Słowa kluczowe: hidradenitis suppurativa, trądzik odwrócony, epidemiologia, Polska.

\section{DEFINITION}

Hidradenitis suppurativa (HS, inflammation of apocrine sweat glands, acne inversa) is a chronic, inflammatory, recurrent, debilitating disease of hair follicles that usually presents after puberty with painful, deep-seated, inflamed lesions in the apocrine gland-bearing areas of the body, most commonly the axillaries, inguinal and anogenital regions (Dessau definition, 1st International Conference on Hidradenitis suppurativa/Acne inversa, March 30-April 1, 2006, Dessau, Germany) [1, 2].

\section{DIAGNOSIS}

To establish the diagnosis of HS, the disease must meet three primary diagnostic criteria. Firstly, it must involve typical skin lesions which are characteristic of HS, i.e. deep-seated painful nodules, abscesses, draining sinuses (inflamed tunnels), bridged scars and pseudo-comedones. Most commonly, various skin lesions enumerated above develop concurrently. Secondly, the lesions must be localized in at least one of the areas of predilection including the axillae, groins, perianal region, buttocks or infra- and inter-mammary folds in women [3]. The lesions may occur ectopically, however in order to fulfil the diagnostic criteria, they must involve the areas of predilection listed above. Thirdly, the disease must be shown to have a chronic and recurrent course with at least two flares (relapses) over a period of 6 months. A correct diagnosis may be aided by the presence of other non-pathognomonic factors which additionally confirm HS (Table 1).

\section{DEFINICJA}

Hidradenitis suppurativa (HS, ropne zapalenie apokrynowych gruczołów potowych, trądzik odwrócony) jest przewlekłą, zapalną, nawrotową, wyniszczającą dermatozą mieszków włosowych, która zwykle pojawia się po okresie dojrzewania płciowego i objawia się występowaniem bolesnych, głęboko umiejscowionych zmian zapalnych w okolicach ciała zawierających apokrynowe gruczoły potowe, najczęściej w obrębie pach, pachwin i okolicy anogenitalnej (definicja z Dessau, 1. Międzynarodowa konferencja nt. hidradenitis suppurativa/trądziku odwróconego, 30 marca - 1 kwietnia 2006 r., Dessau, Niemcy) [1, 2].

\section{ROZPOZNANIE}

Do ustalenia rozpoznania HS konieczne jest spełnienie trzech pierwszorzędowych kryteriów diagnostycznych. Po pierwsze, muszą być obecne typowe zmiany skórne charakterystyczne dla HS, tj. głębokie, bolesne guzki podskórne, ropnie, drenujące przetoki (tunele zapalne), mostkowate blizny oraz pseudozaskórniki. Najczęściej różne wymienione powyżej zmiany występują jednocześnie. Po drugie, zmiany muszą się znajdować przynajmniej w jednym z obszarów predylekcyjnych (pachy, pachwiny, okolica okołoodbytnicza, pośladki, u kobiet fałdy pod- i śródpiersiowe) [3]. Zmiany mogą się pojawiać ektopowo, ale powinny obejmować powyższe obszary predylekcyjne, aby spełnić kryteria diagnozy HS. Po trzecie, wymagane jest stwierdzenie przewlekłego i nawrotowego przebiegu - przynajmniej dwa zaostrzenia (nawroty) w ciągu 6 miesięcy. W postawieniu prawidłowej diagnozy mogą być pomocne inne niepatognomoniczne

Table I. Non-pathognomonic factors supporting the diagnosis of hidradenitis suppurativa

Tabela I. Niepatognomoniczne czynniki pomocne w rozpoznaniu hidradenitis suppurativa

- positive family history of hidradenitis suppurativa/rodzinny wywiad w kierunku hidradenitis suppurativa

- recurrent uncharacteristic inflammatory skin lesions (e.g. folliculitis, open comedones) in typical locations/nawrotowe, zapalne, niecharakterystyczne zmiany skórne (np. folliculitis, otwarte zaskórniki) w miejscach typowych

- typical lesions in non-predilection areas (mainly in high friction areas, e.g. on the abdomen due to belt rubbing against the skin)/ charakterystyczne zmiany w miejscach niepredylekcyjnych (najczęściej w miejscach zwiększonego tarcia, np. na brzuchu wskutek tarcia przez pasek)

- presence or positive family history of pilonidal cyst/obecność bądź dodatni wywiad w kierunku zatoki włosowej

- absence of pathogenic microbial flora in cultures from purulent lesions/brak patogennej flory mikrobowej w posiewach ze zmian ropnych 


\section{CLASSIFICATION AND ASSESSMENT OF SYMPTOM SEVERITY}

Among various HS classification systems (PGA, HSS, HSSI, AISI and others), Hurley's staging system remains the most widespread in daily medical practice on account of its intuitive and non-time consuming nature. Since Hurley's staging system is repeatedly referred to in the present paper, it requires a brief characterization. In 1989, Hurley [4] proposed the first classification system for the severity of disease symptoms. Accordingly, stage I involves the formation of solitary or multiple isolated abscesses without sinus tracts and scarring. Stage II is characterized by recurrent single or multiple well-formed abscesses accompanied by sinus tracts and scarring, and stage III is distinguished by the presence of multiple abscesses interconnected by sinus tracts covering the entire affected location. Stage I is the most commonly observed among patients with HS $(68 \%)$. Stage II is found in $28 \%$ of all patients, and stage III - in $4 \%$ of HS patients [5]. As mentioned above, Hurley's classification is still in prevalent use nowadays, and since there is no other validated threestage classification system, Hurley's successive stages (I/II/III) are recognized as corresponding to mild, moderate and severe HS, respectively.

\section{EPIDEMIOLOGY}

\section{Situation in the USA and Europe}

Published papers on the epidemiology of HS reveal clear discrepancies in the estimation of the obtained results for the general population. The majority of authors agree the mean age of disease onset is in early adulthood (20-30 years of age), with predisposed individuals including women, persons with marked obesity and smokers. Also, most experts concur that the maximum duration of the active form of HS in a given patient is about 20 years [6]. With regard to the estimated prevalence of the disease in European countries and in the United States, available data differ by up to four orders of magnitude, ranging from $0.00033 \%$ to $4.1 \%$ [7-18].

The aim of these studies was to assess the prevalence of HS by estimating the number of all cases of the disease or the number of new cases in different groups (hospital vs. population-based studies) in varying periods (from 1968 until 2017) and using diverse diagnostic methods (information submitted by the patient, physician's assessment, based on diagnosis code retrieved automatically from medical information systems), which in addition to the above mentioned significant estimation discrepancies also gave rise to uncertainty regarding the actual prevalence of HS [6]. czynniki, które dodatkowo potwierdzają rozpoznanie HS (tab. 1).

\section{KLASYFIKACJA I OCENA NASILENIA OBJAWÓW}

Spośród rozmaitych systemów klasyfikacji HS (m.in. PGA, HSS, HSSI, AISI) system oceny zaawansowania choroby wg Hurley jest nadal najpowszechniej stosowany w codziennej praktyce lekarskiej, gdyż jest intuicyjny i nieczasochłonny. Zostanie on także niejednokrotnie użyty na potrzeby niniejszej pracy, więc wymaga krótkiego scharakteryzowania. W 1989 r. Hurley [4] jako pierwsza zaproponowała klasyfikację nasilenia objawów HS: stadium I to tworzenie się ropni, pojedynczych lub mnogich, bez przetok i bliznowacenia, stadium II to jeden ropień lub większa liczba nawracających, wyraźnie wykształconych ropni z wytworzeniem przetok i bliznowaceniem, a stadium III - liczne ropnie, połączone między sobą przetokami, zajmujące obszar całej określonej lokalizacji. Stadium I choroby obserwuje się najczęściej (68\% pacjentów), stadium II występuje u $28 \%$ pacjentów, natomiast stadium III u $4 \%$ pacjentów z HS [5]. Dziś klasyfikacja wg Hurley, jak wspomniano powyżej, jest nadal powszechnie używana, a ponadto kolejne stadia (I, II, III) utożsamia się odpowiednio z łagodnym, umiarkowanym i ciężkim HS (nie ma innej 3-stopniowej, zwalidowanej skali).

\section{EPIDEMIOLOGIA}

\section{Sytuacja w USA i Europie}

Przyglądając się pracom epidemiologicznym dotyczącym HS, stosunkowo łatwo dostrzec znaczne rozbieżności w estymacji uzyskiwanych wyników na populację ogólną. Większość autorów jest zgodna, że średni wiek rozpoczęcia się choroby to okres wczesnej dorosłości (20-30 lat), a predysponowane są kobiety, osoby ze znaczną nadwagą oraz palące tytoń. Większość ekspertów jest również zgodna, że czas trwania czynnej postaci HS wynosi u danego pacjenta maksymalnie ok. 20 lat [6]. Dane dotyczące częstości występowania choroby w krajach europejskich i USA różnią się nawet o 4 rzędy wielkości i mieszczą się w przedziale od 0,00033\% do 4,1\% [7-18].

Celem badań była ocena częstości występowania HS na podstawie liczby wszystkich przypadków choroby lub liczby nowych zachorowań w różnych grupach (szpital vs badania populacyjne), w różnych okresach (od 1968 do 2017 r.) i przy zastosowaniu różnych metod diagnostycznych (informacja udzielona przez pacjenta, ocena dokonana przez lekarza, na podstawie kodu rozpoznania uzyskanego automatycznie w systemach informacji medycznej). Doprowadziło to, oprócz wyżej wspomnianego istotnego zróżnicowania ocen, 
It seems, however, that the most objective method for estimating the prevalence of a given disease relies on medical databases gathering information about a considerable number of patients treated in various healthcare systems. However, a considerable importance is also attached to meticulous reporting and correct coding of a given disease: the codes for HS are L73.2 (according to ICD-10) or 705.83 (according to ICD-9-CM). For many years, medical data derived from registers kept in the United States have been recognized as the standard to follow.

One study assessed the incidence of HS in a group of ca. 144,000 inhabitants of a county in the state of Minnesota (USA) [19]. The source of data was the Rochester Epidemiology Project, a medical information system collecting medical data from hospitals, outpatient clinics, private practices and nursing homes based in the county. Between 1968 and 2008, a total of 268 HS cases were identified, corresponding to a mean incidence of 6.0 per 100,000 person-years, with a double incidence increase between the borderline years of the period (4 to 10 per 100,000 person-years). The increase may be attributed to improved detectability of the disease and assignment of appropriate diagnosis codes in the medical information system. A strong point of the study was that it assessed the incidence of HS for the first time. However, a limitation was its retrospective nature. Assuming that the maximum duration of active disease in HS patients is approximately 20 years, incidence can be extrapolated to calculate the prevalence of the disease $=$ incidence $\times$ disease duration.

Accordingly, the prevalence of HS would be:

- maximum: 10/100,000 person-years $\times 20$ years $=$ $200 / 100,000=0.20 \%$,

- minimum: 4/100,000 person-years $\times 20$ years $=$ $80 / 100,000=0.08 \%$.

The conclusion is consistent with experts' opinions and with the findings of the study conducted three years later by other authors using the same register, with the prevalence of HS amounting to $0.13 \%$ [20].

In another US epidemiological study [16], based on the PharMetrics database containing information on insurance-covered healthcare services provided to $15,054,519$ people, the prevalence of HS was estimated at $0.05 \%$. Also, it needs to be stressed that the percentage rate of patients subjected to any procedure for HS (Current Procedural Terminology (CPT) codes 11450, 11451, 11462, 11463, 11470, 11471, 10060 and 10061), most likely corresponding to patients with stage II and III disease according to Hurley's classification, was markedly lower, amounting to just $0.004 \%$. As the authors claim, the study might have been affected by systematic selection bias, since it involved only patients covered by healthcare insurance. do wątpliwości dotyczących rzeczywistej częstości występowania HS [6].

Wydaje się, że najbardziej obiektywną metodą oszacowania występowania tej choroby jest wykorzystanie baz medycznych, które gromadzą znaczne liczby pacjentów leczonych w różnych systemach opieki zdrowotnej. Nie bez znaczenia pozostaje skrupulatność raportowania oraz prawidłowe kodowanie danej jednostki chorobowej - dla HS jest to L73.2 (wg ICD-10) lub 705.83 (wg ICD-9-CM). Od lat za wzór przyjmuje się dane medyczne pochodzące z rejestrów prowadzonych w USA.

W badaniu przeprowadzonym $\mathrm{w}$ hrabstwie w stanie Minnesota (USA) oceniano zapadalność na HS w grupie ok. 144000 mieszkańców [19]. Źródłem był Rochester Epidemiologic Project, system informacji medycznej zbierający dane ze szpitali, przychodni, od lekarzy prywatnych i z domów opieki w obrębie hrabstwa. W latach 1968-2008 zidentyfikowano 268 przypadków HS, co dało średnią zapadalność na poziomie 6,0 na 100000 osobolat i dwukrotne zwiększenie zapadalności między latami granicznymi dla tego okresu (4 do 10 na 100000 osobolat). Wzrost ten może wynikać ze zwiększenia rozpoznawalności HS i oznaczania odpowiednim kodem rozpoznania w systemie informacji medycznej. Mocnym punktem tego badania było to, że po raz pierwszy oszacowano zapadalność na HS, natomiast ograniczeniem jego retrospektywny charakter. Przy założeniu, że czas trwania czynnej postaci HS wynosi u danego pacjenta maksymalnie ok. 20 lat, na podstawie zapadalności można poprzez ekstrapolację obliczyć częstość występowania HS w następujący sposób: częstość występowania $=$ zapadalność $\times$ czas trwania choroby.

Zgodnie z tym założeniem częstość występowania HS wynosi:

- maksymalnie: 10/100 000 osobolat $\times 20$ lat $=200$ / $100000=0,20 \%$;

- minimalnie: $4 / 100000$ osobolat $\times 20$ lat $=80 /$ $100000=0,08 \%$.

Taki wniosek potwierdza opinia ekspertów, a także badanie przeprowadzone 3 lata później przez innych autorów korzystających z tego samego rejestru, gdzie częstość występowania HS wynosiła 0,13\% [20].

W innym amerykańskim badaniu epidemiologicznym [16] opartym na bazie danych PharMetrics o objętych ubezpieczeniem świadczeniach zdrowotnych 15054519 osób oszacowano, że częstość występowania HS wynosi 0,05\%. Należy podkreślić, że odsetek pacjentów, u których przeprowadzono jakąkolwiek procedurę zabiegową w związku z HS [kody CPT (Current Procedural Terminology) - 11450, 11451, 11462, 11463, 11470, 11471, 10060 oraz 10061], a więc najprawdopodobniej pacjentów w stadiach Hurley II i III, był znacznie niższy i wynosił zaledwie 0,004\%. Jak informują autorzy, możliwe było wystąpienie błędu sys- 
Consequently, the obtained results may be non-representative for the general population.

A recently published retrospective population-based study, also relying on a medical register of patients comprising 27 integrated healthcare organizations in the USA, was aimed at determining the prevalence of HS in a population of over 48 million patients [7]. The prevalence of HS in the study was estimated at $0.01 \%$. The results also referred exclusively to insured individuals, however since the study population was so large, by the authors' admission they seem to reflect the actual trend for the prevalence of the disease in the USA. It should be emphasized, though, that there could be significant differences between the study population and the population of Europe, Poland in particular. Another noteworthy observation is that the prevalence of HS among African American patients (representing nearly one third of the study population) was approximately three times higher. It is important to note that the US population is commonly known to be obese (body mass index BMI $\geq 30 \mathrm{~kg} / \mathrm{m}^{2}$ ). Based on the Trust for America's Health report (2016), the percentage of obese individuals in the population varies across the states from $20.2 \%$ (Colorado) to $36.2 \%$ (Louisiana). It is thus easy to see that the values are nearly twice as high as in European countries where, based on the results obtained in the European Health Interview Survey (EHIS) in 2014 , obese individuals in Poland accounted for $16.7 \%$ of the overall population aged 15 and older. Poland's figure was higher than the mean value determined for 28 European Union countries, where the percentage of obese persons is $15.4 \%$ [21, 22]. It can thus be concluded that the extrapolation of data derived from the studies presented above to the European population might result in a slight overestimation.

A question arises as to why the results reported in the few available European studies estimate the prevalence of HS to be about $1 \%$. Most likely, it can be attributed to the fact that relatively small populations were included in analyses, and the studies were conducted with questionable tools or methods of disease validation. The largest European study by Revuz et al. [13], encompassing a sample of the French population (10,000 people), involved self-reporting of the disease by subjects in a survey which was returned by $68.9 \%$ of the respondents. Another study taken into account, which was conducted by Jemec et al. [10], included an assessment of a randomly selected group of 793 individuals invited by letter to undergo a medical examination. It can be presumed that people with various disorders (including skin diseases) were more willing to report for the examination than potentially healthy individuals. Also, the study group itself (599 subjects) was not representative for the population of the country as a whole. tematycznego selekcji, ponieważ badanie dotyczyło wyłącznie osób objętych ubezpieczeniem zdrowotnym i wyniki mogą nie być reprezentatywne dla populacji ogólnej.

W ostatnio opublikowanym badaniu populacyjnym o charakterze retrospektywnym, opartym na medycznym rejestrze pacjentów obejmującym 27 zintegrowanych organizacji ochrony zdrowia w USA, oceniono częstość występowania HS u ponad 48 milionów pacjentów [7]. W przypadku tej pracy częstość występowania HS wynosiła 0,01\%. Uzyskane wyniki także dotyczyły wyłącznie osób ubezpieczonych, ale ze względu na tak dużą grupę badaną, co podkreślają autorzy, wydaje się, że odzwierciedlają one faktyczny trend występowania tej choroby w USA. Warto jednak podkreślić, że w porównaniu z populacją europejską, zwłaszcza polską, badana grupa mogła się znacząco różnić. Wśród Afroamerykanów (stanowiących blisko 1/3 grupy badanej) występowanie HS było ok. 3-krotnie częstsze. Ponadto powszechnie wiadomo, że populacja USA jest grupą ludzi otyłych [wskaźnik masy ciała (body mass index - BMI) $\geq 30 \mathrm{~kg} / \mathrm{m}^{2}$ ]. Odsetek ludzi otyłych różni się między stanami i waha się wg raportu Trust for America's Health z 2016 r. od 20,2\% (Kolorado) do 36,2\% (Luizjana). Łatwo dostrzec, że są to wartości niemal 2-krotnie większe niż w krajach europejskich. Według Europejskiego Ankietowego Badania Zdrowia (EHIS) z 2014 r. osoby otyłe w Polsce stanowiły 16,7\% osób w wieku 15 lat i więcej. Był to wynik powyżej średniej dla 28 krajów Unii Europejskiej wynoszącej 15,4\% otyłych [21, 22]. Można stwierdzić, że dane uzyskane z powyższych prac przy ekstrapolacji na warunki europejskie mogą dawać nieco zawyżone wyniki.

Dlaczego wyniki dotyczące częstości występowania HS płynące z nielicznych europejskich badań są na poziomie ok. 1\%? Najprawdopodobniej przyczyną są stosunkowo nieliczne oraz dyskusyjne narzędzia lub metody walidacji choroby. W największym europejskim badaniu przeprowadzonym przez Revuz i wsp. [13] obejmującym grupę 10000 Francuzów respondenci diagnozowali u siebie chorobę sami na podstawie ankiety, na którą odpowiedziało $68,9 \%$ $\mathrm{z}$ nich. $\mathrm{W}$ innym branym pod uwagę badaniu, przeprowadzonym przez Jemeca i wsp. [10], oceniano losowo wybraną grupę 793 osób, które zostały zaproszone listownie, aby poddały się badaniu lekarskiemu. Można się domyślać, że na badania częściej wybierały się osoby, które cierpiały na różne schorzenia (w tym skórne) niż osoby potencjalnie zdrowe. Grupa badana (599 osób) nie była reprezentatywna dla populacji całego kraju.

W przeciwieństwie do dwóch powyżej wymienionych badań dane płynące z rejestrów włoskich, szacowane na populację ogólną $[8,23]$ wskazują, że 
Unlike the two studies presented above, data obtained from Italian registers and estimated for the general population $[8,23]$ indicate that the prevalence of HS reaches $0.045 \%$ and $0.056 \%$.

\section{Situation in Poland}

Aspects relevant to the epidemiology of HS in Poland are addressed below. The register of patients using public healthcare services in Poland is maintained by the National Health Fund (NFZ). According to the 2015 data, a total of about 35 million people (i.e. over $90 \%$ of the Polish population) were eligible for public healthcare (including insured individuals and other persons covered). Data obtained from the NFZ Department of Healthcare Services (Warsaw Headquarters) for the period from 2014 to 2016 show that the number of HS patients (L73.2) was 367, 373 and 440 in the consecutive years, which corresponds to a mean prevalence of $0.001 \%$. The figures translate to an average of 110 patients with Hurley stage II HS and 16 patients with stage III HS every year (estimation based on the European S1 guideline [6]). The result obtained in this manner appears to be underestimated in relation to the data derived from the largest US and European medical databases presented above, though it is within the range specified in the introductory section $(0.00033 \%$ to $4.1 \%)$. Another point to note is that the detectability and awareness of HS among dermatologists in Poland is high, which is an important factor, considering that they are the main group providing treatment to HS patients. On the other hand, not all patients report their HS-associated symptoms to a dermatologist or, for that matter, to any physician. This holds particularly true for patients with mild severity of the disease. In addition, the ICD-10 code of the disease has been translated into Polish rather imprecisely as "multiple abscesses of axillary apocrine sweat glands (hydradenitis suppurativa)", which may lead to an underestimation of results. Moreover, attention should be given to the number of patients with HS who are treated at centres specializing in treatment of this entity, primarily at the Department of Dermatology, Venereology and Allergology, Wroclaw Medical University, but also at the Department of Dermatology, Venereology and Paediatric Dermatology, Medical University of Lublin; Department of Dermatology, Sexually Transmitted Diseases and Clinical Immunology, University of Warmia and Mazury in Olsztyn; and at the Department of Dermatology, Paediatric Dermatology and Dermatological Oncology, Medical University of Lodz. These medical centres provide treatment to patients refractory to classical therapy who are referred from all over Poland, which is evident in NFZ records (with close to half of all HS cases in Poland being reported in four provinces listed). During 3 consecutive years included in the analysis (i.e. 2014-2016), a total of częstość występowania HS była na poziomie 0,045\% i $0,056 \%$.

\section{Sytuacja w Polsce}

Jak wygląda epidemiologia HS w Polsce? Rejestr pacjentów korzystających z publicznych świadczeń zdrowotnych w naszym kraju prowadzony jest przez Narodowy Fundusz Zdrowia (NFZ). Według danych z 2015 r. uprawnienia (ubezpieczeni i osoby uprawnione) do świadczeń opieki zdrowotnej miało ogółem ok. 35 milionów osób (ponad 90\% populacji polskiej). Według danych Departamentu Świadczeń Opieki Zdrowotnej NFZ, Centrala w Warszawie w latach 2014-2016 r. odnotowano odpowiednio 367, 373 i 440 pacjentów z HS (L73.2), co daje średnią częstość występowania na poziomie 0,001\%. Przekłada się to średnio na 110 pacjentów w stadium II nasilenia choroby wg Hurley i 16 pacjentów w stadium III w ciągu każdego roku (estymacja na podstawie European S1 guideline [6]). Wynik wydaje się zaniżony w stosunku do prezentowanych powyżej danych pochodzących z największych baz medycznych w USA i Europie, chociaż mieści się w podanym na wstępie przedziale, tj. od 0,00033\% do 4,1\%. Ponadto należy uwzględnić, że rozpoznawalność i świadomość HS wśród dermatologów w Polsce jest duża, a jest to przecież główna grupa lecząca tych chorych. Nie wszyscy pacjenci z HS zgłaszają się jednak ze swoimi dolegliwościami do dermatologa bądź do lekarza w ogóle (szczególnie ci z nieznacznym nasileniem choroby). Ponadto nazwa tej jednostki chorobowej w polskiej wersji językowej ICD-10 przetłumaczona została dość niefortunnie - „ropnie mnogie gruczołów apokrynowych pachy (hydradenitis suppurativa)", co może zaniżać wyniki. Warto zwrócić także uwagę na liczby pacjentów z HS leczonych w ośrodkach specjalizujących się w terapii tej jednostki chorobowej, przede wszystkim w Katedrze i Klinice Dermatologii, Wenerologii i Alergologii Uniwersytetu Medycznego we Wrocławiu, a także w Katedrze i Klinice Dermatologii, Wenerologii i Dermatologii Dziecięcej Uniwersytetu Medycznego w Lublinie, Katedrze i Klinice Dermatologii, Chorób Przenoszonych Drogą Płciową i Immunologii Klinicznej Uniwersytetu Warmińsko-Mazurskiego w Olsztynie oraz Katedrze i Klinice Dermatologii i Dermatologii Dziecięcej i Onkologicznej Uniwersytetu Medycznego w Łodzi, do których kierowani są pacjenci z całej Polski z HS niepoddającym się "klasycznej” terapii, co zresztą widać w danych z rejestru NFZ (w czterech wymienionych województwach raportuje się blisko połowę wszystkich przypadków HS w Polsce). W Klinice we Wrocławiu hospitalizowano w 3 kolejnych poddanych analizie latach (tj. 2014-2016) 178 pacjentów z HS (średnio 60 rocznie, co stanowiło około połowy 
178 patients with HS were hospitalized in the Department in Wroclaw (i.e. on average 60 patients per year, which accounted for nearly half of cases diagnosed yearly in the province concerned). The other Departments listed above provided hospitalization on average to a total of about 15 patients with HS a year. They were almost exclusively patients with stage II and III disease according to Hurley's staging system, in whom prior conservative treatment (predominantly antibiotic therapy or systemic retinoids) failed to produce a clinically significant improvement, and who required biological treatment or surgical intervention (in most cases).

\section{CONCLUSIONS}

In the light of US and European literature data, it seems that previous figures on the prevalence of HS ( $1 \%)$ were markedly overestimated. The actual prevalence of HS seems to be about $\leq 0.1 \%$, especially in European countries. Based on the NFZ data, the prevalence of HS in Poland is $0.001 \%$. Consequently, HS should be recognized as a rare disease in line with the definition recommended in the European Union, whereby a disease is classified as rare if it affects not more than 5 per 10,000 persons [24]. The conclusion is consistent with observations made in day-to-day medical practice: patients with HS are seen significantly less frequently than patients with psoriasis which has an estimated prevalence of $0.09 \%$ (Tanzania) to $11.4 \%$ (Norway) [25].

\section{CONFLICT OF INTEREST}

The authors declare no conflict of interest. corocznych rozpoznań dla województwa). Kolejne wymienione kliniki hospitalizowały łącznie średnio ok. 15 pacjentów z HS rocznie. Były to niemal wyłącznie osoby z nasileniem choroby w stadium II i III wg Hurley, u których dotychczasowe leczenie zachowawcze (głównie antybiotykoterapia bądź retinoidy podawane ogólnie) nie przyniosło istotnej klinicznie poprawy i którzy wymagali leczenia biologicznego lub interwencji chirurgicznej (najczęściej).

\section{PODSUMOWANIE}

W świetle najnowszych danych z piśmiennictwa USA i Europy wydaje się, że dotychczasowe szacunki dotyczące występowania HS (ok. 1\%) były znacznie zawyżone. Można przypuszczać, że prawdziwa częstość występowania HS jest na poziomie $\leq 0,1 \%$, zwłaszcza w krajach europejskich. Oszacowana na podstawie danych z NFZ częstość wstępowania HS w Polsce wynosząca 0,001\% pozwala uważać HS za chorobę rzadką, gdyż zgodnie z definicją zalecaną w Unii Europejskiej chorobę uznaje się za rzadką, jeśli dotyka nie więcej niż 5 na 10000 osób [24]. Znajduje to potwierdzenie w codziennej praktyce lekarskiej, gdzie pacjentów z HS widuje się o wiele rzadziej niż pacjentów z łuszczycą, której częstość występowania ocenia się na $0,09 \%$ (Tanzania) do 11,4\% (Norwegia) [25].

\section{KONFLIKT INTERESÓW}

Autorzy deklarują brak konfliktu interesów.

\section{References}

Piśmiennictwo

1. Fimmel S., Zouboulis C.C.: Comorbidities of hidradenitis suppurativa (acne inversa). Dermatoendocrinology 2010, 2, 9-16.

2. Kurzen H., Kurokawa I., Jemec G.B., Emtestam L., Sellheyer K., Giamarellos-Bourboulis E.J., et al.: What causes hidradenitis suppurativa? Exp Dermatol 2008, 17, 455-472.

3. van der Zee H.H., Jemec G.B.: J New insights into the diagnosis of hidradenitis suppurativa: clinical presentations and phenotypes. J Am Acad Dermatol 2015, 73 (5 Suppl. 1), S23-S26.

4. Hurley H.: Axillary hyperhidrosis, apocrine bromhidrosis, hidradenitis suppurativa, and familial benign pemphigus: surgical approach. [In:] Dermatologic Surgery. Roenigh R.R.H. (eds.), Marcel Dekker, New York, 1989, 729-739.

5. Canoui-Poitrine F., Revuz J.E., Wolkenstein P., Viallette C., Gabison G., Pouget F., et al.: Clinical characteristics of a series of 302 French patients with hidradenitis suppurativa, with an analysis of factors associated with disease severity. J Am Acad Dermatol 2009, 61, 51-57.

6. Zouboulis C.C., Desai N., Emtestam L., Hunger R.E., Ioannides D., Juhász I., et al.: European S1 guideline for the treatment of hidradenitis suppurativa/acne inversa. J Eur Acad Dermatol Venereol 2015, 29, 619-644.

7. Garg A., Kirby J.S., Lavian J., Lin G., Strunk A.: Sex- and age-adjusted population analysis of prevalence estimates for hidradenitis suppurativa in the United States. JAMA Dermatol 2017; doi: 10.1001/jamadermatol.2017.0201 [in press].

8. Fania L., Ricci F., Sampogna F., Mazzanti C., Didona B., Pintori G., et al.: Prevalence and incidence of hidradenitis suppurativa: an exercise on indirect estimation from psoriasis data. J Eur Acad Dermatol Venereol 2017; doi: 10.1111/jdv.14224 [in press].

9. Lookingbill D.P.: Yield from a complete skin examination: findings in 1157 new dermatology patients. J Am Acad Dermatol $1988,18,31-37$

10. Jemec G.B., Heidenheim M., Nielsen N.H.: The prevalence of hidradenitis suppurativa and its potential precursor lesions. J Am Acad Dermatol 1996, 35, 191-194.

11. Jemec G.B.: The symptomatology of hidradenitis suppurativa in women. Br J Dermatol 1988, 119, 345-350. 
12. von der Werth J.M., Williams H.C.: The natural history of hidradenitis suppurativa. J Eur Acad Dermatol Venereol 2000, 14, 389-392.

13. Revuz J.E., Canoui-Poitrine F., Wolkenstein P., Viallette C., Gabison G., Pouget F., et al.: Prevalence and factors associated with hidradenitis suppurativa: results from two case-control studies. J Am Acad Dermatol 2008, 59, 596-601.

14. Jemec G.B.: Clinical practice: hidradenitis suppurativa. N Engl J Med 2012, 366, 158-164.

15. Vinding G.R., Miller I.M., Zarchi K., Ibler K.S., Ellervik C., Jemec G.B.: The prevalence of inverse recurrent suppuration: a population-based study of possible hidradenitis suppurativa. Br J Dermatol 2014, 170, 884-889.

16. Cosmatos I., Matcho A., Weinstein R., Montgomery M.O., Stang P.: Analysis of patient claims data to determine the prevalence of hidradenitis suppurativa in the United States. J Am Acad Dermatol 2013, 68, 412-419.

17. Shlyankevich J., Chen A.J., Kim G.E., Kimball A.B.: Hidradenitis suppurativa is a systemic disease with substantial comorbidity burden: a chart-verified case-control analysis. J Am Acad Dermatol 2014, 71, 1144-1150.

18. Shahi V., Alikhan A., Vazquez B.G., Weaver A.L., Davis M.D.: Prevalence of hidradenitis suppurativa: a population-based study in Olmsted County, Minnesota. Dermatology 2014, 229, 154-158.

19. Vazquez B.G., Alikhan A., Weaver A.L., Wetter D.A., Davis M.D.: Incidence of hidradenitis suppurativa and associated factors: a population-based study of Olmsted County, Minnesota. J Invest Dermatol 2013, 133, 97-103.

20. Andersen L.K., Davis M.D.: Prevalence of skin and skin-related diseases in the Rochester epidemiology project and a comparison with other published prevalence studies. Dermatology 2016, 232, 344-352.

21. Piekarzewska M., Wieczorkowski R., Zajenkowska-Kozłowska A.: Stan zdrowia ludności Polski w 2014 r., Główny Urząd Statystyczny, Departament Badań Społecznych i Warunków Życia, Zakład Wydawnictw Statystycznych, Warszawa 2016.

22. Eurostat: Available at: http://ec.europa.eu/eurostat/web/health/health-status-determinants/data/database [Accessed: 9 June 2017]

23. Bettoli V., Pasquinucci S., Caracciolo S., Piccolo D., Cazzaniga S., Fantini F., et al.: The hidradenitis suppurativa patient journey in Italy: current status, unmet needs and opportunities. J Eur Acad Dermatol Venereol 2016, 30, 1965-1970.

24. Available at: http://www.mz.gov.pl/leczenie/choroby-rzadkie [Accessed: 5 June 2017].

25. Global report on psoriasis. ISBN 978924156518 9, WHO 2016.

Received: 27.06 .2017

Accepted: 12.08 .2017

Otrzymano: $27.06 .2017 \mathrm{r}$

Zaakceptowano: 12.08 .2017 r.

How to cite this article

Matusiak Ł., Kaszuba A., Krasowska D., Placek W., Szepietowski J.: Epidemiology of hidradenitis suppurativa in Poland in relation to international data. Dermatol Rev/Przegl Dermatol 2017, 104, 377-384. DOI: https://doi.org/10.5114/dr.2017.69945. 